\title{
ANALISIS SENTIMEN ZOOM CLOUD MEETINGS DI PLAY STORE MENGGUNAKAN NAÏVE BAYES DAN SUPPORT VECTOR MACHINE
}

\author{
Nuraeni Herlinawati*1, Yuri Yuliani ${ }^{2}$, Siti Faizah ${ }^{3}$, Windu Gata ${ }^{4}$, Samudi $^{5}$
}

\author{
Ilmu Komputer STMIK Nusa Mandiri \\ Jl. Damai No.8, Warung Jati Barat (Margasatwa), Jakarta Selatan \\ 1nuraeni.nhw@nusamandiri.ac.id, ${ }^{2} y u r i . y y i @ n u s a m a n d i r i . a c . i d,{ }^{3}$ siti.sfz@nusamandiri.ac.id, \\ ${ }^{4}$ windu@nusamandiri.ac.id, ${ }^{5}$ samudi.smx@nusamandiri.ac.id
}

\begin{abstract}
Abstrak - Aplikasi zoom cloud meetings yang mulai booming digunakan sekarang ini karena adanya pandemi virus corona, sehingga membuat semua kegiatan dilakukan secara virtual. Zoom cloud meetings merupakan aplikasi yang memiliki berbagai fitur termasuk video \& audio conference. Pada penelitian ini penulis menggunakan metode Naïve Bayes dan Support Vector Machine dalam menganalisa label sentimen positif atau negatif pada ulasan para pengguna aplikasi zoom di Google Play Store. Jumlah dataset setelah prepocessing menjadi 1.007 record. Data hampir seimbang dengan label positif sebanyak 546 dan label negatif 461 ulasan. Evaluasi model menggunakan 10 fold cross validation diperoleh nilai akurasi dan nilai AUC dari masingmasing algoritma yaitu untuk NB nilai akurasi $=74,37 \%$ dan nilai AUC $=0,659$. Sedangkan untuk algoritma SVM nilai akurasi $=81,22 \%$ dan nilai AUC $=0,886$. Dalam penelitian ini dapat diketahui bahwa tingkat akurasi yang didapatkan algoritma Support Vector Machine (SVM) lebih unggul 6,85\% dibandingkan algoritma Naïve Bayes (NB).
\end{abstract}

Kata Kunci_Z Zoom Cloud Meetings, Google Play Store, Virus Corona, Naïve Bayes, Support Vector Machine.

Abstract-Zoom cloud meetings application that began to boom is used today because of the corona virus pandemic, so that all activities are carried out virtually. Zoom cloud meetings is an application that has various features including video \& audio conferencing. In this study the authors used the Naive Bayes method and Support Vector Machine in analyzing positive or negative sentiment labels on the zoom users' reviews on the Google Play Store. The number of datasets after prepocessing is 1,007 records. The data is almost balanced with 546 positive labels and 461 negative labels. Evaluation of the model using 10 fold cross validation obtained accuracy values and AUC values from each algorithm, namely for NB, the accuracy value = $74.37 \%$ and the AUC value $=0.659$. As for the SVM algorithm the accuracy value $=81.22 \%$ and the AUC value $=0.886$. In this study it can be seen that the accuracy obtained by the Support Vector Machine (SVM) algorithm is $6.85 \%$ superior to the Naïve Bayes (NB) algorithm.

Keywords - Zoom Cloud Meetings, Google Play Store, Corona Virus, Naïve Bayes, Support Vector Machine.

\section{PENDAHULUAN}

Penggunaan aplikasi zoom cloud meetings yang mulai booming akhir-akhir ini karena adanya kasus wabah virus corona yang melanda hampir di semua Negara termasuk Negara Indonesia. Salah satu kebijakan pemerintah untuk menekan jumlah penyebaran virus corona adalah himbauan agar tidak keluar dari rumah, para pekerja diminta untuk bekerja dari rumah atau work from home (WFH), begitupun para pelajar dan mahasiswa agar belajar dari rumah atau study from home (SFH), sehingga membuat semua kegiatan dilakukan secara virtual karena adanya kebijakan tersebut [1]. Kegiatan belajar mengajar sekarang ini tidak bisa dilakukan di ruangan kelas secara langsung seperti biasanya, kini beralih menjadi e-learning yang di support oleh banyak aplikasi, salah satunya adalah aplikasi zoom cloud meetings yang paling sering digunakan oleh para pengajar (guru atau dosen) dalam melakukan pembelajaran, sehingga dibuatlah virtual class.

Zoom cloud meetings merupakan aplikasi yang sangat diminati karena sangat reliable, mudah digunakan, dengan fitur video \& audio conference, collaboration, chat, webinar, shared screen, shared file dengan konsep room system dan dapat diakses dari desktop maupun smartphone [2].

Play Store merupakan layanan penyedia konten digital milik Google yang menyediakan berbagai toko produk online seperti aplikasi, game, film atau musik, dan buku dengan beragam kategori. Google Play Store dapat diakses melalui website, aplikasi android, dan Google TV. Pada Google Play Store terdapat beberapa fitur salah satunya adalah fitur rating dan ulasan dari para pengguna aplikasi atau layanan yang tersedia. Review atau ulasan merupakan suatu teks atau kalimat yang berisi penilaian atau komentar terhadap suatu hasil karya seseorang. Pentingnya ulasan tersebut sering digunakan sebagai tolak ukur suatu aplikasi 
apakah recommended atau tidak bagi para pengguna baru [3]

Analisis sentimen adalah suatu proses komputasi dengan memahami, mengekstrak dan mengolah data tekstual secara otomatis untuk mendapatkan sebuah informasi sentimen yang terdapat dalam suatu kalimat opini atau pendapat, perilaku dan emosi seseorang terhadap entitas (menggambarkan individu, kejadian atau topik), tujuannya menyediakan informasi berharga bagi seseorang yang terkandung dari sebuah dataset yang tidak terstruktur. Besarnya pengaruh dan manfaat dari analisis sentimen menyebabkan penelitian dan aplikasi berbasis analisis sentimen berkembang sangat pesat, sudah banyak perusahaan yang memfokuskan pada layanan analisis sentimen [4].

Pada penelitian ini analisis sentimen dilakukan untuk melihat ulasan dari para pengguna aplikasi zoom cloud meetings, ulasan tersebut bisa dimasukkan kedalam dua kategori yaitu positif dan negatif.

Klasifikasi Nä̈ve Bayes (NB) yang sering digunakan merupakan algoritma pembelajaran yang didasarkan pada teori Bayes dengan menggunakan asumsi yang kuat, bahwa efek dari suatu nilai atribut sebuah kelas yang diberikan adalah bebas, tidak tergantung pada kelas atau tidak dipengaruhi atribut lain. Teori Bayes adalah teori tentang klasifikasi statistik yang dapat memprediksi atribut kelas suatu anggota probabilitas berdasarkan data yang sudah ada [5].

Support Vector Machine (SVM) adalah metode klasifikasi dan regresi yang biasa digunakan untuk masalah linear dan non linear. Mempunyai kelebihan dalam menerapkan pemisahan linear pada input data non linear berdimensi tinggi, dan ini diperoleh dengan menggunakan fungsi kernel yang diperlukan. Efektivitas Support Vector Machine sangat dipengaruhi oleh jenis fungsi kernel yang dipilih dan diterapkan berdasarkan karakteristik data. Sudah banyak penelitian yang melaporkan bahwa Support Vector Machine merupakan metode yang paling akurat untuk teks klasifikasi [6].

Pada penelitian sebelumnya mengenai analisis sentimen Korps Brigade Mobil Kepolisian Indonesia berdasarkan posting twitter menggunakan metode SVM Dan NB, menghasilkan nilai akurasi dengan pendekatan SVM 86,96\% nilai presisi $86,96 \%$, dan nilai recall $86,96 \%$ [7]. Penelitian mengenai perbandingan metode klasifikasi analisis sentimen tokoh politik pada komentar media berita online, menggunakan metode klasifikasi NB dan SVM mendapatkan hasil bahwa, SVM adalah metode terbaik dengan akurasi 78,40\% dan AUC 0,850 [8]. Hasil penelitian algoritma Nä̈ve Bayes, Decision Tree, dan SVM untuk klasifikasi persetujuan pembiayaan nasabah Koperasi Syariah menunjukan akurasi algoritma Nä̈ve Bayes 77,29\%, Decision Tree 89,02\% dan yang tertinggi Support Vector Machine 89,86\% [9]. Penelitian tentang implementasi video conference dengan file sharing menggunakan WebRTC mengemukakan bahwa terdapat layanan untuk berbagi data atau file sharing ketika melakukan video conference. Aplikasi yang mendukung video conference dan file sharing adalah Skype, Cisco Webex, dan Zoom. WebRTC dapat berjalan pada semua browser, open source, dan gratis [10].

Tujuan penelitian ini untuk memprediksi label sentimen pada ulasan dari para pengguna aplikasi zoom cloud meetings di Google Play Store menggunakan metode Nä̈ve Bayes dan Support Vector Machine sebagai model klasifikasi, ulasan atau review tersebut bisa dimasukkan kedalam dua kategori yaitu positif dan negatif.

\section{METODE PENELITIAN}

Pada penelitian ini penulis menggunakan metode Nä̈ve Bayes dan Support Vector Machine untuk menghasilkan akurasi terbaik dalam menganalisa label sentimen pada ulasan dari para pengguna aplikasi zoom cloud meetings di Google Play Store. Proses yang dilakukan agar mampu menghasilkan akurasi terbaik adalah sebagai berikut :

\section{A. Pengambilan Data}

Pengambilan data pada penelitian ini didapatkan dari ulasan para pengguna aplikasi zoom cloud meetings di Google Play Store, dengan menggunakan teknik web scraping (data miner) yakni suatu teknik yang digunakan untuk mengekstrak data dalam jumlah besar dari situs web dimana data yang sudah diekstraksi disimpan ke sebuah file lokal di komputer atau database dalam format tabel (spreadsheet), kemudian diproses menggunakan tools RapidMiner untuk masuk ke tahap selanjutnya yaitu prepocessing atau pemrosesan data.

\section{B. Pemrosesan Data}

Tahap selanjutnya adalah melakukan persiapan data yang telah didapat agar dapat terolah pada saat melakukan pemodelan. Tahap prepocessing atau pemrosesan data mencakup kegiatan membangun data dan juga membersihkan data agar siap untuk dikelola ke tahap modelling atau pemodelan data. Berikut ini tahap pemrosesan data antara lain :

1) Regex Removal : menghilangkan regular expression yang ada dalam teks.

2) Remove URL : menghapus URL yang terdapat dalam teks.

3) Annotation Removal : menghilangkan tanda @ (annotation) yang ada dalam teks.

4) Remove Number : menghapus angka yang terdapat dalam teks.

5) Tokenization : proses tokenisasi pada data teks adalah melakukan pemecahan sekumpulan kalimat menjadi potongan karakter atau kata-kata sesuai kebutuhan yang sering disebut token, sehingga menjadi kata yang memiliki arti tertentu.

6) Stemming : menghilangkan imbuhan yang terdapat pada masing-masing kata sehingga menjadi 
kata dasar, juga bertujuan untuk membersihkan suatu kata dengan pengejaan yang kurang tepat. Algoritma stemming untuk bahasa yang satu berbeda dengan algoritma stemming untuk bahasa lainnya.

7) Transform Case : mengubah semua huruf besar atau kapital dalam data menjadi huruf kecil ataupun sebaliknya. Hal ini dilakukan agar ketika masuk ke tahap pemodelan klasifikasi terdapat keseragaman huruf dan tidak terjadi kesalahan dalam proses tokenize, yang biasa digunakan adalah mengubah semua huruf menjadi huruf kecil (lower case).

8) Filter Stopwords : sebuah proses untuk menghilangkan kata-kata yang tidak mempunyai arti yang biasanya merupakan kata sambung, kata keterangan dan sebagainya pada hasil parsing sebuah dokumen teks dengan cara membandingkannya dengan stoplist berisi kata-kata yang terlalu sering muncul dalam dokumen-dokumen, belum tentu berguna dalam proses retrieval, kemungkinan besar tidak akan memberikan pengaruh prediksi. Kata-kata yang tidak berguna nantinya akan dibuang dan tidak dijadikan index term. Tahap ini merupakan proses untuk melakukan filter terhadap kata-kata umum seperti "the", " $a$ ", "it", "they" dan lainnya, yang tidak diperlukan saat pemrosesan data.

9) Filter Tokens (By Length) : menghilangkan kata dengan panjang huruf tertentu. Misalnya minimal 2 karakter dan maksimal 25 karakter. Artinya kata yang panjangnya hanya 1 karakter dan lebih dari 25 karakter akan dihilangkan.

10) Labelling : merupakan tahap dimana hasil dari tahapan sebelumnya akan dilakukan perhitungan terhadap polarity dari ulasan yang terambil, sehingga dapat menghasilkan dua kategori yaitu label positif dan negatif, untuk label netral (nilai $=0$ ) tidak diproses

\section{Pemodelan Data}

Pada tahap ini melakukan analisis data berdasarkan algoritma yang telah ditentukan yakni Nä̈ve Bayes dan Support Vector Machine. Pada tahapan ini dilakukan 10 fold cross validation yakni proses membagi dataset menjadi 10 bagian yang mana 1 diantara bagian lainnya menjadi data testing, dan yang lainnya menjadi data training. Hasil pengujian model yang dilakukan adalah mengklasifikasikan label positif dan negatif pada ulasan para pengguna aplikasi zoom cloud meetings di Google Play Store menggunakan algoritma Nä̈ve Bayes dan Support Vector Machine untuk mendapatkan nilai akurasi terbaik. Tools yang digunakan adalah RapidMiner, untuk saat ini versi yang terbaru adalah 9.6 [11].

Klasifikasi Nä̈ve Bayes merupakan klasifikasi yang bersifat supervised learning karena memiliki supervisor (manusia melakukan klasifikasi secara manual pada data yang digunakan dalam pelatihan) selaku pengajar dalam proses belajar atau learning. Selain itu, performansi Nä̈ve Bayes memiliki waktu klasifikasi yang singkat sehingga mempercepat proses sistem analisis sentimen [12].

Kelebihan dari Support Vector Machine (SVM) adalah : mempunyai kemampuan generalisasi yang tinggi, mampu menghasilkan model klasifikasi yang baik meskipun dilatih dengan himpunan data yang relatif sedikit hanya dengan pengaturan parameter yang sederhana, SVM memiliki konsep dan formulasi yang jelas dengan sedikit parameter yang harus diatur, relatif mudah diimplementasikan karena penentuan SVM dapat dirumuskan dalam masalah QP (Quadratic Programming) [13].

\section{Evaluasi}

Setelah tahapan modelling selesai maka selanjutnya adalah melakukan evaluasi terhadap hasil dari pemodelan tersebut. Membandingkan dua hasil dari pemodelan yang berupa accuracy dan AUC (Area Under Curve) antara model. Tahapan evaluasi bertujuan untuk menentukan nilai kegunaan dari model yang telah berhasil dibuat pada langkah sebelumnya. Untuk evaluasi digunakan 10 fold cross validation. Melakukan evaluasi performa akurasi dan AUC dari eksperimen yang telah dilakukan.

\section{HASIL DAN PEMBAHASAN}

Penulis akan menjelaskan mengenai proses yang dijalankan dalam penelitian ini, tools yang digunakan adalah RapidMiner dalam menerapkan metode algoritma yang telah ditentukan. Ada beberapa langkah yang diterapkan pada penelitian ini, yakni :

\section{A. Pengambilan Data}

Pengambilan data pada penelitian ini didapatkan dari ulasan para pengguna aplikasi zoom cloud meetings di Google Play Store, dengan menggunakan teknik web scraping (add-on dari Google Chrome yakni data miner). Dataset yang terambil sebanyak 1.158 ulasan, kemudian diproses menggunakan tools RapidMiner, setelah prepocessing untuk label netral (nilai $=0$ ) diabaikan maka dataset menjadi 1.007 ulasan, jumlah data hampir seimbang (balanced) setiap labelnya, karena dengan data yang tidak seimbang (imbalanced), klasifikasi yang dibangun memiliki kecenderungan untuk mengabaikan minority class. Data dengan label positif sebanyak 546 ulasan dan label negatif 461 ulasan. 


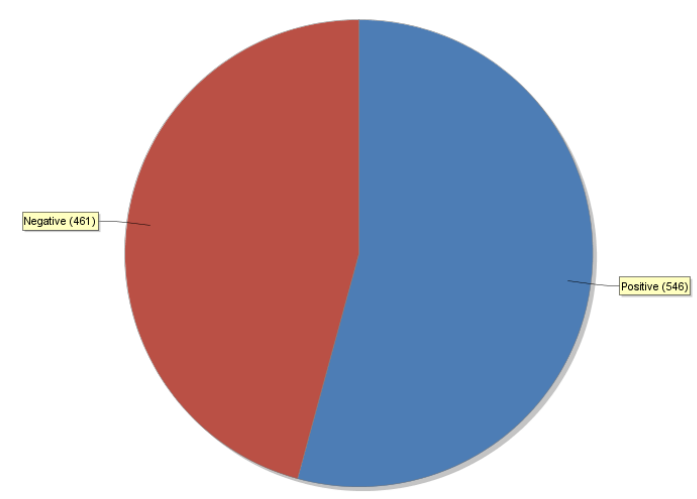

Gbr. 1 Perbandingan label positif dan negatif

\section{B. Pemrosesan Data}

Setelah pengambilan data dari website, tahap selanjutnya adalah melakukan persiapan data yang telah didapat agar dapat terolah pada saat melakukan pemodelan. Tahap prepocessing mencakup kegiatan membangun data dan juga membersihkan data agar siap untuk dikelola ke tahap modelling. Dalam prepocessing ini terbagi dalam beberapa langkah : Regex Removal, Remove URL, Annotation Removal, Remove Number, Tokenization, Stemming, Transform Case, Filter Stopwords, Filter Tokens (By Length), Labelling. Gambar 2 dan 3 merupakan pemrosesan data menggunakan RapidMiner.
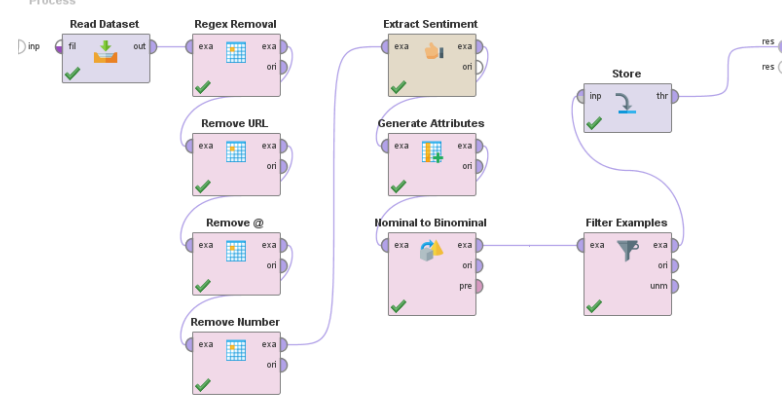

Gbr. 2 Pemrosesan data awal

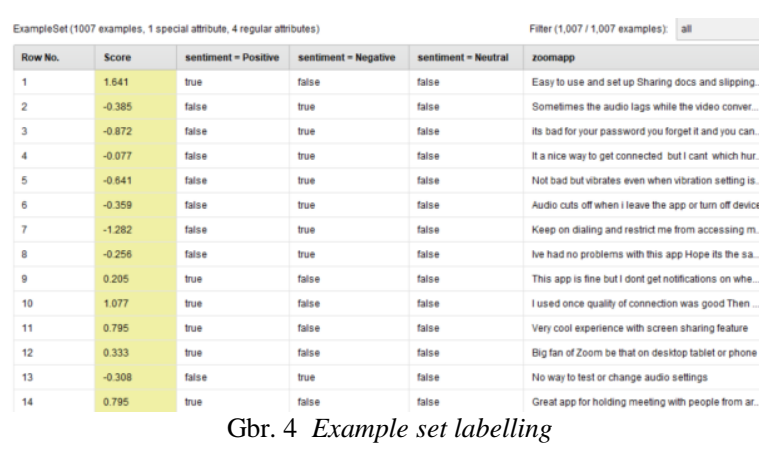

\section{Pemodelan Data}

Hasil pengujian model yang dilakukan adalah mengklasifikasikan label positif dan negatif pada ulasan para pengguna aplikasi zoom cloud meetings di Google Play Store menggunakan algoritma Nä̈ve Bayes dan Support Vector Machine untuk mendapatkan nilai akurasi terbaik. Gambar 5 menunjukan pemodelan data Nä̈ve Bayes dan Support Vector Machine.

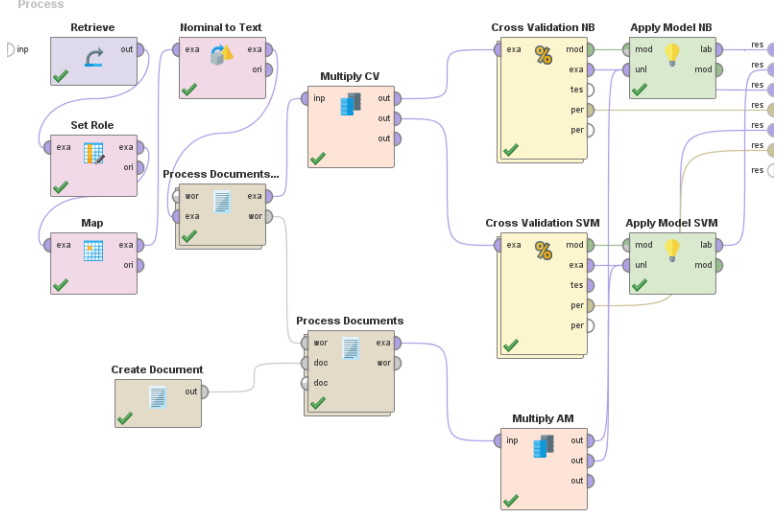

Gbr. 5 Pemodelan data NB \& SVM

Pada tahapan ini dilakukan 10 fold cross validation pada masing-masing metode algoritma. Gambar 6 merupakan cross validation Nä̈ve Bayes. Gambar 7 merupakan cross validation Support Vector Machine.

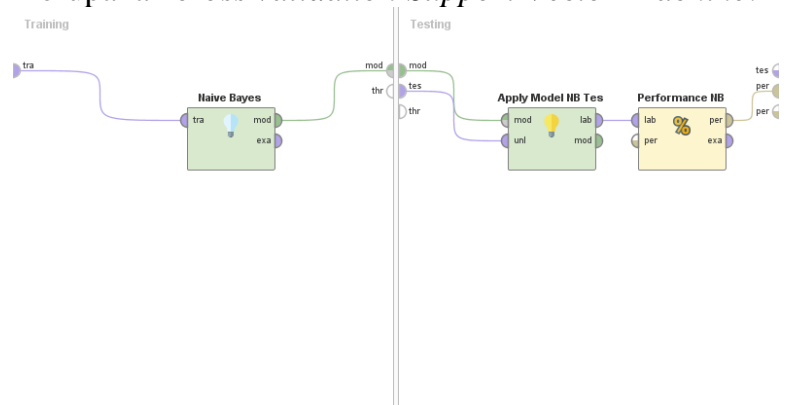

Gbr. 6 Cross validation Nä̈ve Bayes

Gbr. 3 Pemrosesan data lanjutan 

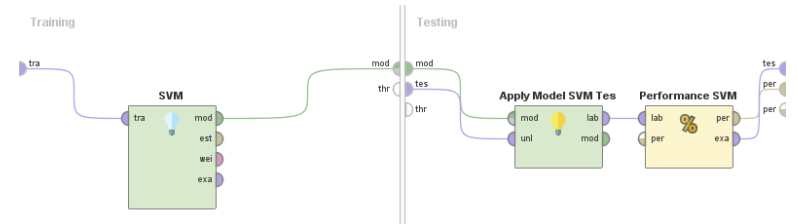

Gbr. 7 Cross validation Support Vector Machine

\section{Evaluasi}

Setelah tahapan modelling selesai maka selanjutnya adalah melakukan evaluasi terhadap hasil dari pemodelan tersebut. Membandingkan dua hasil dari pemodelan algoritma Nä̈ve Bayes (NB) dan Support Vector Machine (SVM) yang berupa accuracy dan AUC (Area Under Curve) antara model. Evaluasi bertujuan untuk menentukan nilai kegunaan dari model yang telah berhasil dibuat pada langkah sebelumnya. Untuk evaluasi digunakan 10 fold cross validation. Melakukan evaluasi performa akurasi dan AUC dari eksperimen yang telah dilakukan. Evaluasi dilakukan dengan menggunakan confusion matrix yaitu true positive rate (TP rate), true negative rate (TN rate), false positive rate (FP rate) dan false negative rate (FN rate) sebagai indikator. TP rate adalah persentase dari kelas positif yang berhasil diklasifikasi sebagai kelas positif, sedangkan TN rate adalah persentase dari kelas negatif yang berhasil diklasifikasi sebagai kelas negatif. FP rate adalah kelas negatif yang diklasifikasi sebagai kelas positif. FN rate adalah kelas positif yang diklasifikasi sebagai kelas negatif.

Dari hasil pengujian model diatas dengan menggunakan algoritma NB maka dapat menghasilkan sebuah nilai accuracy (confusion matrix) yang dapat dilihat pada Gambar 8. Jumlah TP rate adalah 411 record diklasifikasikan sebagai label positif dan FP rate adalah 135 record diklasifikasikan sebagai label negatif. Berikutnya jumlah TN rate adalah 338 record diklasifikasikan sebagai label negatif dan FN rate adalah 123 record diklasifikasikan sebagai label positif. Berdasarkan Gambar 8 menunjukan bahwa tingkat akurasi dengan menggunakan algoritma NB sebesar 74,37\%. Pada Gambar 9 nilai Area Under Curve (AUC) sebesar 0,659 dengan performance yang kurang begitu baik.

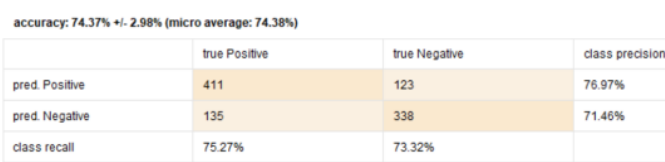

Gbr. 8 Accuracy algoritma Nä̈ve Bayes

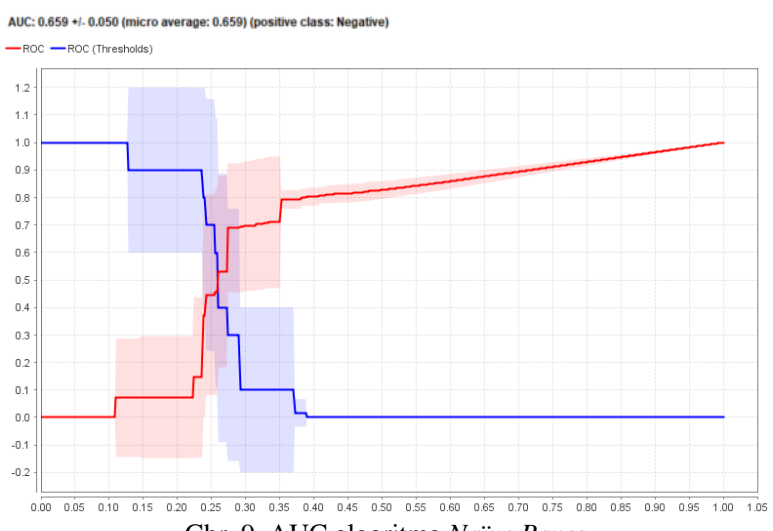

Gbr. 9 AUC algoritma Nä̈ve Bayes

Dari hasil pengujian model diatas dengan menggunakan algoritma SVM maka dapat menghasilkan sebuah nilai accuracy (confusion matrix) yang dapat dilihat pada Gambar 10. Jumlah TP rate adalah 473 record diklasifikasikan sebagai label positif dan FP rate adalah 73 record diklasifikasikan sebagai label negatif. Berikutnya jumlah TN rate adalah 345 record diklasifikasikan sebagai label negatif dan FN rate adalah 116 record diklasifikasikan sebagai label positif. Berdasarkan Gambar 10 menunjukan bahwa tingkat akurasi dengan menggunakan algoritma SVM sebesar 81,22\%. Pada Gambar 11 nilai Area Under Curve (AUC) sebesar 0,886 dengan performance yang baik.

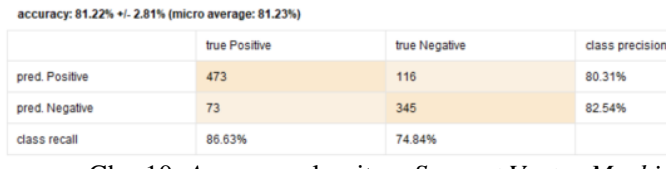

Gbr. 10 Accuracy algoritma Support Vector Machine

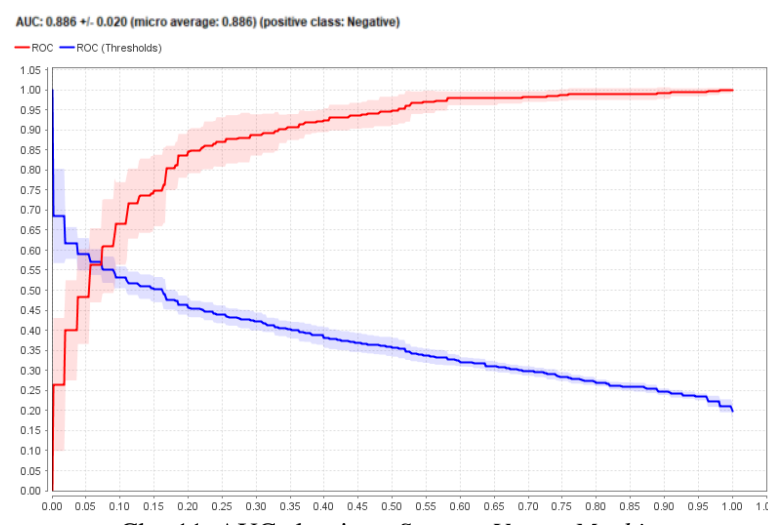

Gbr. 11 AUC algoritma Support Vector Machine

\section{KESIMPULAN}

Berdasarkan hasil analisis dari masing-masing algoritma diatas yakni Nä̈ve Bayes (NB) dan Support Vector Machine (SVM), maka dapat dirangkum hasilnya seperti pada tabel berikut ini : 
TABEL I

CONFUSION MATRIX SETIAP ALGORITMA

\begin{tabular}{|c|c|c|c|c|}
\hline Metode & TP & FP & TN & FN \\
\hline Nä̈ve Bayes & 411 & 135 & 338 & 123 \\
\hline Support Vector Machine & 473 & 73 & 345 & 116 \\
\hline
\end{tabular}

Page | 298

TABEL III

PERBANDINGAN PERFORMANCE ALGORITMA

\begin{tabular}{|c|c|c|}
\hline Metode & Accuracy & AUC \\
\hline Nä̈ve Bayes & $74,37 \%$ & 0,659 \\
\hline Support Vector Machine & $81,22 \%$ & 0,886 \\
\hline
\end{tabular}

Dalam penelitian ini setelah dilakukan prepocessing dan modelling dengan membandingkan dua metode algoritma data mining yaitu Nä̈ve Bayes (NB) dan Support Vector Machine (SVM), dari hasil evaluasi diketahui bahwa nilai akurasi untuk mengklasifikasikan label positif dan label negatif pada ulasan para pengguna aplikasi zoom cloud meetings di Google Play Store, dapat dibuktikan dengan nilai akurasi dan nilai AUC dari masing-masing algoritma yaitu untuk NB nilai akurasi $=74,37 \%$ dan nilai AUC $=0,659$. Sedangkan untuk algoritma SVM nilai akurasi $=81,22 \%$ dan nilai $\mathrm{AUC}=0,886$. Dalam penelitian ini dapat diketahui bahwa tingkat akurasi yang didapatkan algoritma Support Vector Machine (SVM) lebih unggul 6,85\% dibandingkan algoritma Näive Bayes (NB) dengan 1.007 record dataset. Banyak terdapat penelitian sebelumnya yang menggunakan algoritma Support Vector Machine dengan dataset berbeda menghasilkan akurasi yang baik ketika dibandingkan dengan algoritma lainnya.

\section{REFERENSI}

[1] T. Dewayani, "Bekerja dari Rumah (Work From Home) Dari Sudut Pandang Unit Kepatuhan Internal," Kanwil DJKN Jawa Barat, 2020. [Online]. Available: https://www.djkn.kemenkeu.go.id/artikel/baca/13014/Bekerjadari-Rumah-Work-From-Home-Dari-Sudut-Pandang-UnitKepatuhan-Internal.html.

[2] Zoom, "Zoom Solutions," Zoom Video Communications, Inc, 2020. https://zoom.us/.

[3] S. A. Saputra, D. Rosiyadi, W. Gata, and S. M. Husain, "Analisis Sentimen E-Wallet Pada Google Play Menggunakan Algoritma Naive Bayes Berbasis Particle Swarm Optimization," J. Resti, vol. 3, no. 3, pp. 377-382, 2019.

[4] G. A. Buntoro, "Analisis Sentimen Calon Gubernur DKI Jakarta 2017 Di Twitter," Integer J., vol. 2, no. 1, pp. 32-41, 2017 [Online]. Available: https://www.researchgate.net/profile/Ghulam_Buntoro/publicati on/316617194_Analisis_Sentimen_Calon_Gubernur_DKI_Jaka rta_2017_Di_Twitter/links/5907eee44585152d2e9ff992/Analisi s-Sentimen-Calon-Gubernur-DKI-Jakarta-2017-Di-Twitter.pdf.

[5] A. Fauzi, A. N. Rais, M. F. Akbar, and W. Gata, "Analisis Sentimen Berinternet Pada Media Sosial AMIK BSI Tegal Dengan Menggunakan Algoritma Naive Bayes," in Seminar Nasional Teknologi Informasi Universitas Ibn Khaldun Bogor, 2018, pp. 46-54.

[6] I. Santoso, W. Gata, and A. B. Paryanti, "Penggunaan Feature Selection di Algoritma Support Vector Machine untuk Sentimen Analisis Komisi Pemilihan Umum," J. Resti, vol. 3, no. 3, pp. 364-370, 2019.

[7] B. Pratama et al., "Sentiment Analysis of the Indonesian Police Mobile Brigade Corps Based on Twitter Posts Using the SVM And NB Methods," J. Phys. Conf. Ser., pp. 1-12, 2019, doi 10.1088/1742-6596/1201/1/012038.
[8] S. Kurniawan, W. Gata, D. A. Puspitawati, N. Nurmalasari, M Tabrani, and K. Novel, "Perbandingan Metode Klasifikasi Analisis Sentimen Tokoh Politik Pada Komentar Media Berita Online," J. Resti, vol. 3, no. 2, pp. 176-183, 2019.

[9] N. Nurajijah and D. Riana, "Algoritma Naïve Bayes, Decision Tree, dan SVM untuk Klasifikasi Persetujuan Pembiayaan Nasabah Koperasi Syariah," J. Teknol. dan Sist. Komput., vol. 7, no. 2, pp. 77-82, 2019, doi: 10.14710/jtsiskom.7.2.2019.77-82.

[10]F. N. Azzam, D. P. Kartikasari, and F. A. Bakhtiar, "Implementasi Video Conference dengan File Sharing menggunakan WebRTC," J. Pengemb. Teknol. Inf. dan Ilmu Komput., vol. 3, no. 10, pp. 10102-10109, 2019, [Online]. Available: http://j-ptiik.ub.ac.id.

[11] RapidMiner, "RapidMiner Studio 9.6," RapidMiner, 2020. https://my.rapidminer.com/nexus/account/index.html\#download s.

[12] B. Gunawan, H. S. Pratiwi, and E. E. Pratama, "Sistem Analisis Sentimen pada Ulasan Produk Menggunakan Metode Naive Bayes," J. Edukasi dan Penelit. Inform., vol. 4, no. 2, pp. 113118, 2018, doi: 10.26418/jp.v4i2.27526.

[13] H. Hermanto, A. Mustopa, and A. Y. Kuntoro, "Algoritma Klasifikasi Naive Bayes Dan Support Vector Machine Dalam Layanan Komplain Mahasiswa," JITK (Jurnal Ilmu Pengetah. dan Teknol. Komputer), vol. 5, no. 2, pp. 211-220, 2020, doi: 10.33480/jitk.v5i2.1181 